\title{
Exploring Indonesian EFL Writing Students' Differences in Motivation: A Language Learning Journey to Success
}

\author{
Listyani Listyani \\ English Language Education Program (ELEP), UKSW, Salatiga, Indonesia
}

\begin{abstract}
Every language learner has various dreams and purposes in learning a language. Different motivations are also commonly found among EFL learners. This study reveals the motivations of 33 English language learners from Indonesia. They were all writing students of an English Language Education Program (ELEP) in a private university in Central Java, Indonesia. The classes they attended were Procedural Writing (14 students from the 2020 class year), Research Report Writing (10 students from the 2017 class year), and Research Proposal (9 students from the 2018 class year). Data were derived through questionnaires and interviews. The first finding was that $\mathbf{8 7 . 8 8 \%}$ of the respondents were intrinsically motivated. However, both intrinsic and extrinsic motivation might be a big drive leading to students' success. The second discovery was that $81.82 \%$ of the students were instrumentally rather than integratively motivated. Instrumental motivation could also be a big initiative for students to learn a language. Next, students' ideals or dreams became the motivating factor that most students had. The last outcome was that students' habit of delaying doing assignments, having too many assignments, and being lazy were the three major demotivating factors. This study will hopefully be useful for writing lecturers to give them more insights into and a better understanding of their students' motivational backgrounds.
\end{abstract}

Index Terms-motivations, language learning, success

\section{INTRODUCTION}

In 1985, Kachru proposed a model of the three circles of English. They are the inner circle, outer circle, and expanding circle (Valpa, 2020). Living in the expanding circle in which English is not the first nor the second language, many learners in Indonesia lack exposure to this international language. The case is different from the counterparts living in the inner or outer circle. They get a lot of exposure and inputs every day. The expanding circle included more than 750 million speakers of English as a Foreign Language (EFL) in 1997. This number is far from the speakers of the inner and outer circles, that is, 375 million people each (UKessays, 2018). There is a gap between the ideal, dreamed situation and the reality for the learners in the expanding circle. It is many people's dream to be able to have good competence in English. However, in reality, many things become obstacles for English language learners. One of the problems is motivation.

Motivation is a never-ending topic to be discussed and researched. Numerous studies have been done to explore the sources and factors influencing motivation, causes of loss of motivation, types of motivation, and many other aspects related to this continuous topic under discussion. Much attention has also been given to learners' motivation in second or foreign language learning. Various topics related to language learning motivation have been explored.

Many researchers have also connected motivation to the idea of self-concepts like self-image, self-confidence, selfesteem, and some other related notions. There are many great experts in the study of motivation, namely Ellis, Deci and Ryan, Gardner, and Dörnyei, all of whose theories complement one another. Ellis, one of the leading figures in the study of motivation, mentioned that motivation is the extent to which language learners strive to acquire a second or foreign language. Motivation results from the learners' need or desire to learn the language (Ellis, 1994, in Mahadi \& Jafari, 2012).

Other great figures in motivation are Deci and Ryan. They were the founding fathers of SDT (the Self-Determination Theory). They mentioned that SDT is an approach dealing with human motivation and personality. This theory uses traditional empirical methods. Besides that, this theory employs an "organismic meta-theory". It emphasizes the importance of people's intrinsic resources. These resources grow for human personality development and the behavior's self-regulation (Ryan, Kuhl, \& Deci, 1997, in Ryan \& Deci, 2000, p. 68). Thus, it is very close to the investigation of human fundamental growth and natural psychological needs. These needs become the base for self-motivation, integration of personality, also for the situations that support positive processes.

Another famous figure, Gardner (2001), as cited in Lai (2013), stated that basically, motivation includes three aspects. They are an effort to learn the language, desire to reach a goal, and positive effect to enjoy the language learning tasks. Dörnyei (1994) asserted that motivation is one of the main determining factors in SLA or FLA (second or foreign language learning). In the last three decades, there has been a lot of research investigating the nature and role of 
motivation in the process of second language learning. Motivation, as mentioned by Dörnyei (1994), grows uniquely and dynamically. Motivation is essential to gain success in areas where prolonged learning takes place.

Dörnyei (1998, in Nikoopour, Salimian, Salimian, \& Farsani, 2012), emphasized further the importance of motivation. He stated that not only does motivation act as a trigger to initiate language learning, but it can also compensate for some learners' weaknesses like a lack of aptitude. Dörnyei (1994) also added that motivation is one of the main determining factors for the success and achievement of second or foreign language learning.

Motivation is indeed a never-ending topic that is always interesting to be discussed and explored. It is one of the determining factors of the success of second and foreign language learners. Without motivation, language learning may not be successful. Looking at the need to research this area, the researcher thus initiated this study. This study focuses on the motivation that EFL learners in Indonesia, which is positioned in the expanding circle, have in terms of writing. Since the researcher was teaching several kinds of writing classes, this research was thus conducted in three different writing courses that the researcher taught in Semester II of the 2020-2021 academic year.

Three research questions are addressed in this study: (1) What kind of motivation do these writing students have? (2) What are the reasons behind their motivations? And (3) Are there any factors that demotivate these students? The participants of this study were thirty-three students of different writing classes: Procedural Writing, Proposal Writing, and Thesis Report Writing. The purpose of this study is thus to describe those EFL writing learners' motivation in their language-learning journey. This study will hopefully be useful to give insights for writing lecturers about different students' motivations. Other than that, this study is hopefully useful for research in the area of SLA, in which motivation is learned as one of the individual learner differences.

\section{A. What Is Motivation?}

"Motivation" comes from the Latin word, movere. It means "to move" (Sabet, Tahriri, \& Haghi, 2014, citing from Hindi \& Boscolo, 2007). In terms of writing, for example, when we say that writers are motivated to write, it means they are motivated to write. Furthermore, these writers try hard through their writing to stimulate the readers or audience. Previous research depicted a significant connection between motivation and students' performance. Sabet, Tahriri, and Haghi (2014) also claimed that writing is a multifaceted activity. It necessitates methodical attention to the motivational conditions (Bruning \& Horn, 2000).

Tulgar (2018) also pointed out that for language learning success, there are two important keys. The first one is the significance of having the desire to learn a new language. The second is keeping a positive attitude towards the target language. Citing from Gardner (1985), Tulgar (2018) further explained that motivation is the combination of efforts and desire to achieve language-learning goals. Besides that, there should be a positive attitude toward language learning. Considering the process of language learning from the beginning to the end, Dörnyei (1998, in Tulgar, 2018), defined language-learning motivation as the primary push to start L2 learning. Later on, the motivation will become a powerful force to support the long and arduous learning process. Dörnyei (1998, in Sabet, Tahriri, \& Haghi, 2014), further explained that even individuals with remarkable abilities will not be able to accomplish the long-term goals of language learning if they do not have sufficient motivation. This is one of the primary dynamics in language learning success. In foreign language classrooms, there are some effective ways to increase students' motivation. Building up group cohesiveness and having good learning experiences are two of them. The effects of group harmony can be particularly strong in language classes (Dörnyei, 1997, p. 485, in Ning \& Hornby, 2014).

\section{B. The Elements of Motivation}

Gardner (1985 \& 2010), in Wallace and Leong (2020), revealed that three aspects are found in learning motivation. These include the need to attain a learning goal, the attitude sustained in pursuing the goal, and the efforts put forth in realizing it. Highly motivated learners will generally depict a resilient need and a positive attitude to reach their desired learning goals. They will make an effort to achieve their goals. On the other hand, low-motivated learners possess a lack of need to learn. They also demonstrate negative attitudes toward the material. Furthermore, they display little effort in accomplishing their goals.

Wallace and Leong (2020) further claimed that the following elements are needed to stay motivated: an effort, a positive attitude, a desire, and a goal. If one of these components is absent, it may depict a lack of motivation. If a learner strives to be a proficient language user but does not make a concerted effort, the learner will not be able to achieve one's goal. Therefore, the learner can be classified as being unmotivated.

\section{The Types of Motivation}

Therefore, it is obvious that language learners are affected by internal and external motivational factors. Some of the internal factors may be interested in the topic being studied, its supposed value, and students' attitudes toward the material. External factors which influence students' motivation are the social support for learning that is given by parents, teachers, and peers, and their opinions of the formal learning context (Williams \& Burden, 1997, in Wallace \& Leong, 2020). Internal traits are frequently displayed as separate constructs that affect motivation. Thus, they are deemed intertwined with the learner's learning context (Waninge, Dörnyei, \& de Bot, 2014).

In language learning, the theories of motivation came to light as a field of socio-educational research between 1960 and 1990. Gardner (1985, in Bower, 2019), defined integrative motive, which consists of three variables. These 
variables include integrativeness, attitudes towards the learning situation, and the last one is motivation. Gardner claimed that a motivated learner will show 'efforts, desires, and affect' (Gardner, 2001, p. 13). Affect refers to a positive emotional outcome, like interest, pleasure, or enjoyment. Still, regarding intrinsic motivation, Bower (2019) believed that positive aspects drive intrinsic motivation. This is considered to be more influential in supporting efforts than extrinsic motivation. External and instrumental rewards like the need to pass an examination, for instance, create extrinsic motivation.

Gardner also proposed the idea that to learn a second language, a learner needs to be attracted to the target language culture and to the people who speak the language (Gardner 2001; Gardner \& Lambert, 1972, in Bower, 2019). Ning and Hornby (2014) further stated that intrinsic motivation is the most self-determined and autonomous. It involves doing an activity due to the pleasure and satisfaction of the activity rather than because of rewards from external factors. EFL intrinsic motivation also involves the contentment of learning English for its own sake rather than because of the outcomes or results (Ning \& Hornby (2014), citing from Clement, Dörnyei, \& Noels, 1994; Dörnyei, 2001; Noels et al., 2000; Slavin, 2000; Sears \& Pai, 2013).

\section{SDT (Self-Determination Theory)}

Regarding language learning motives, Wallace and Leong (2020) asserted that these motives can also be categorized based on the self-determination theory (Ryan \& Deci, 2020). This implies that learning motivation may be spurred by intrinsic or extrinsic motives. Learners who study for extrinsic reasons seek rewards, for instance, getting a good test score, receiving a reward from their parents, or avoiding punishment like scoring poorly on a test and getting scolded by their parents.

On the other hand, learners who are intrinsically motivated want to study to gain satisfaction from the act of studying itself. These learners appreciate the novelty and challenges of learning a language. They also seek out opportunities to expand their linguistic competence to improve their abilities as foreign language users (Dincer \& Yesilyurt, 2017, in Wallace \& Leong, 2020). Between the two kinds of motivation, those who are intrinsically motivated tend to display greater perseverance in their language studies. They also will stay on the path if they encounter any obstacles. This is because they enjoy being engaged in learning the language (Wallace \& Leong, 2020, citing from Dailey, 2009).

\section{E. The Effects of Motivation on Language Learning}

Dealing with the forceful effects of motivation on learning, research mainly refers to two sets of motivation types. They are intrinsic versus extrinsic motivation, and integrative versus instrumental motivation. Intrinsic motivation can simply be described as the internal desire to learn new things. On the other hand, extrinsic motivation is the external force that directs learners in studying a language (Dörnyei, 1994, in Tulgar, 2018).

In the context of language learning, Tulgar (2018) also stated that motivation is highly related to learners' perceptions of the target language, its culture, and its speakers. Regarding this, Gardner and Lambert (1972), in Tulgar (2018), proposed a socio-educational model. Integrative and instrumental motivations are introduced in this model. This socio-educational model can be considered as the first model that gives great attention to the motivational effects of social and cultural settings on learning. In addition, in this socio-educational model, integrative motivation, just like internal motivation, is closely related to the learners' personal interest in as well as their attitudes towards the target language and community. Integrative motivation is about one's personal interest, longing for, and perseverance in learning (Tulgar, 2018, citing from Horwitz, 1987).

In contrast, instrumental motivation, like external motivation, is more affected by outside factors like receiving a high score on a test or acquiring a good job. Instrumental motivation deals more with the applied or pragmatic advantages that may be gained from the learning process (Tulgar, 2018, citing from Locastro, 2001). Juvonen and Wentzel (1996, as cited in Sabet, Tahriri, \& Haghi, 2014), asserted that recent studies show learners' social motivations impact their academic performance. Various researchers have examined the motivation of students towards their performance in learning different language aspects. Schmidt (1993, as cited in Sabet, Tahriri, \& Haghi, 2014), also postulated that motivated students will focus more on language input than those who are less motivated.

Amjadiparvar and Zarrin (2019) also found a significant and positive correlation between EFL learners' language awareness level and their motivation. Moreover, a significant and positive connection between the EFL learners' level of language awareness and their achievements were also discovered. It is supported by Niezgoda and Röver (2001, in Sabet, Tahriri, \& Haghi, 2014). They pointed out that motivated learners are more capable and aware of grammatical errors. Cook (2001, in Sabet, Tahriri, \& Haghi, 2014), also revealed that motivated learners can better recognize the pragmatic purposes of a language. Besides that, Tateyama (2001, in Sabet, Tahriri, \& Haghi, 2014), established that highly motivated individuals displayed better performance in doing role-plays.

\section{F. Previous Studies}

Some studies have been done in the same field before. Nikoopour, Salimian, Salimian, and Farsani (2012) investigated the relationship between intrinsic/extrinsic motivation and the language learning strategies used by Iranian EFL learners. Seventy-two (72) participants filled in two questionnaires on motivation and language learning strategies. The results showed that intrinsic motivation was significantly related to cognitive and metacognitive strategies. On the other way around, extrinsic motivation was not significantly associated with the use of language learning strategies. In 
addition, it turned out that Iranian learners were mainly intrinsically motivated towards learning the English language. It was also found that they used metacognitive strategies more frequently than other types of strategies.

Kormos and Czizer (2014, in Wallace \& Leong, 2020), explored the connection between self-regulation, motivation, and autonomous learning behavior in a Hungarian second language context. They conveyed that although the students had a strong desire to learn and a positive attitude towards second language learning, without having a concerted effort to study, they could not achieve their learning targets.

In Sabet, Tahriri, and Haghi's (2014) study, there were sixty-eight (68) EFL university student participants at the intermediate level of proficiency. Thirty-two of them received task-based language teaching (TBLT). After eight sessions, the learners were requested to make an abstract for a research paper. A questionnaire based on motivation (adapted from Lam \& Law, 2007) was disseminated to the participants. The questionnaire was comprised of the following motivational aspects: curiosity, challenges, autonomy, real-life significance, recognition, and evaluation. The outcomes established that learners' motivation has a positive correlation to their performance in writing an abstract.

Ning and Hornby (2014) investigated the impacts of cooperative learning on the motivation of tertiary-level English learners. The research applied random selection of participants from two assigned classes at a university in northern China. A pre-test-post-test control group design was used to compare the impact of the Cooperative Learning approach. Traditional whole-class instructions on six aspects of learning motivation - intrinsic motivation, integrated regulation, identified regulation, introjected regulation, external regulation, and amotivation - were applied. The findings suggested that there were significant differences in favor of cooperative learning in improving intrinsic motivation. However, there were no differences in other aspects of motivation that were reported.

Other researchers, Wallace and Leong (2020), researched 23 sixth grade students of a Macau primary school. They filled in an open-ended questionnaire that had 10 items. The study results revealed that the participants were the most highly motivated and studied English for both instrumental and integrative purposes. The instrumental incentives were for work and travel, while the integrative reasons dealt with an aspiration to assimilate with the target language culture. The majority of the participants also recounted that they regarded their teachers in a positive light. This can illuminate why they mostly had a positive perception of learning English. Their families wanted them to score well on tests. Nevertheless, many of their classmates had a negative opinion about learning English. The respondents also shared that they enjoyed playing games and singing songs the most because these activities improved their intrinsic motivation to learn English.

In 2018, Tulgar examined the relationship between a global second language setting and the motivational levels of Turkish learners. The participants were selected by purposeful sampling. There were 10 foreign learners of Turkish who were taking a year-long preparatory class in language education at AtaTömer. The findings revealed that the participants considered taking courses from native speaker teachers as motivating factors. Having intercultural interactions with native speakers and classmates from different countries was also motivating. These learners displayed concerns for preserving their cultural identity in the new community as a demotivating factor in the global second language setting. Another demotivating factor was difficulties related to the language they were learning.

Liu (2020) carried out a study on the motivational factors of Chinese EFL learners from various educational levels and how they perceived their teachers as motivators. Junior high school, senior high school, and university students were given questionnaires and had follow-up interviews. The results showed how teachers' commitment could influence the motivational levels of students.

First, a positive correlation was found between the students' motivational learning intensity and the teachers' degree of commitment. The university students did not believe that the teachers' commitment had as much of an effect on their motivation as it did for the secondary school learners. The university students felt that their teachers were not as motivated in teaching, even though students at the university level had the highest motivation in English learning compared to the other two groups of students. This indicates that adult learners will go along with how devoted they think their teachers are in the actual learning process.

Second, after examining the most influential motivating factors by teachers towards students at various educational levels, it was found that different from university students, secondary school students placed more emphasis on teachers' communication-based aspects. These features included socio-affective characteristics, personality characteristics, and the use of communicative classroom activities. Conversely, the university student participants with a relatively high degree of English proficiency tended to prioritize the teachers' teaching competence.

Furthermore, the secondary school students emphasized more on the communicative teaching styles, while this was not prioritized among tertiary-level students, who preferred that their instructors had enough transferrable knowledge. For the secondary and tertiary education levels, it can be surmised that teachers can motivate students in learning English if the teachers alter their teaching strategies based on the students' respective degrees of fluency, developmental stages, and learning necessities.

Courtney (2017) examined the similarities as well as the differences between primary and secondary foreign language syllabi and pedagogy together with the development of motivation for language learning and second language proficiency. Data from 26 English learners of French aged around 10 until 11 were collected across three-time points over a year. The study employed the use of lesson observations along with questionnaires and focus group interviews to examine the development of attitudes and motivation. The results showed that a sudden shift in pedagogy might 
negatively influence learners' attitudes and their motivation in early secondary level education. Early language learning does appear to generate positive attitudes towards language learning. However, there are still questions around its effectiveness over the long term when learners encounter language teaching that seems to be incompatible with their aims. It was found that learners made significant linguistic progress across the transition phase.

\section{RESEARCH METHODOLOGY}

\section{A. Research Setting}

The research was done at an English Language Education Program (ELEP), in a private university in Central Java. Data were collected in Semester II of the 2020-2021 academic year.

\section{B. Research Participants}

There were 33 students (10 male and 23 female) participants in this study who were taking different writing classes. Fourteen students were taking Procedural Writing class (from the 2020 class year). They were given initials as Student 1 - Student 14). Besides that, there was a Research Proposal class consisting of nine students from the 2018 class year. They were called Student 15 - Student 23. The last class was Research Report Writing (10 students from the 2017 class year), who were named Student 24 - Student 33. Table 1 below clarifies this information.

TABLE 1

STUDENT PARTICIPANTS

\begin{tabular}{ccc}
\hline Name of Classes & Number of Students & Student Initials \\
\hline Procedural Writing & 14 & Student 1 - Student 14 \\
\hline Research Proposal & 9 & Student 15 - Student 23 \\
\hline Research Report & 10 & Student 24 - Student 33 \\
\hline
\end{tabular}

\section{Research Instruments and Procedures}

Data for this study were derived from 33 students taking various writing classes. These 33 students were asked to answer questionnaire items distributed through email at the end of Semester I, in the 2020-2021 academic year. To be more specific, they were asked to fill in the questionnaires in April 2021. The questionnaire items were given in two languages, Indonesian and English. It was because there was a foreign student in the Procedural Writing class. For every number, another column was provided as "additional information". The questionnaire items are as follows.

TABLE 2

BILINGUAL QUESTIONNAIRE ITEMS

\begin{tabular}{l}
\hline 1. Saya memiliki motivasi yang tinggi untuk sukses dari program studi PBI ini. Jelaskan. \\
(I have high motivation to be successful in this English study program. Please explain). \\
\hline 2. Saya memasuki program studi PBI ini atas keingingan saya sendiri. \\
(I entered this study program because of my willingness. Please explain). \\
\hline 3. Saya mempunyai target waktu untuk lulus dalam waktu 4 tahun. \\
(I have a target to graduate within 4 years. Please explain). \\
\hline 4. Hal2 yang paling memotivasi saya untuk belajar di Prodi ini adalah (tolong diisi): \\
(Things that motivate me to study here are: ...). \\
\hline 5. Hal2 yang paling membuat saya tidak bersemangat (tolong diisi): \\
(Things that make me demotivated are: ....).
\end{tabular}

In-depth interviews were also conducted with students with unclear answers. They were Student 7 (from Procedural Writing class), Student 17, Student 20 (from Proposal Writing class), and Student 27 (from Research Report class). Interviews were conducted on July 3, 2021, individually through Google Meet. Those five students were selected as interviewees because they had interesting answers or because their answers were not clear. Questions for the in-depth interviews were clarifications for the students' unclear answers.

\section{RESULTS AND ANALYSIS}

\section{A. Indonesian EFL Writing Students' Motivations to Enter the English Language Education Program (ELEP)}

From the data collected from both the questionnaires as well as the interviews, some important information was found, such as in dealing with the source of motivation, out of 33 students, only 4 students (12.12\%) had extrinsic motivation. They are Student 11, Student 15, Student 27, and Student 32. Student 11 mentioned that the source of motivation to enter the English Language Education Program (ELEP) came from their parents. The other 29 students $(87.88 \%)$ had inner motivation to study at the English Language Education Program (ELEP).

\section{B. Integrative vs. Instrumental Motivation in Learning English}

Another finding deals with integrative and instrumental motivation. Regarding integrative and instrumental motivations, five students were integratively motivated. They were Student 3, Student 7, Student 10, Student 18, and Student 19. One student, Student 15, experienced a change in motivation. First, she wanted to be a successful person by 
learning English, but then, she started to enjoy learning English. She even enjoyed doing any tasks given by her lecturers.

\section{Intrinsic/ Extrinsic Motivation}

According to Ryan and Deci (2000), comparisons between people who have authentic or intrinsic motivation and those who are merely externally controlled for an action, typically reveal that the former, meaning the ones with intrinsic motivation, have more interest, excitement, and confidence, which in turn is manifested as enhanced performance, persistence, and creativity (Ryan \& Deci, 2000). From the facts found in the study, it was shown that students' achievements did not rely on the source of motivation. Those who got motivation from their parents also could be high-achieving students. In this study, there were only four students $(12.12 \%)$ who had extrinsic motivation, while the remaining 29 students $(87.88 \%)$ had intrinsic motivation. However, those who were extrinsically motivated could also achieve well. Table 3 illustrates students with extrinsic motivation and their GPAs.

TABLE 3

STUDENTS' GPA WITH EXTRINSIC MOTIVATION

\begin{tabular}{ccc}
\hline Student Initials & Motivation & GPA \\
\hline 11 & Extrinsic & 3.15 \\
\hline 15 & Extrinsic & 4 \\
\hline 27 & Extrinsic & 3.2 \\
\hline 32 & Extrinsic & 3.03 \\
\hline
\end{tabular}

This is in line with the results of Olusiji's (2016) research. There were 46 respondents in his study. These 46 students were second-year pre-university and first-year degree students. From the questionnaires distributed to these students, it was found that the teacher factor is seen as the most influential factor. Besides that, it was revealed that one human factor which correlated the most highly with students' motivational intensity is parents. This suggests that students' effort towards learning English is a result of parental encouragement, even though the teacher is perceived to play the most significant role in motivating students to learn English.

This is also in line with Listyani and Tananuraksakul's study in 2019. Among 20 Indonesian student respondents, 14 students (70\%) admitted that the people around them like their parents, friends, or relatives as well as their future jobs influenced them the most in their motivation to learn English. In short, it can be concluded that students with extrinsic motivation may also achieve well, even though the achievement may not be as good as students with intrinsic motivation.

\section{Integrative/ Instrumental Motivation}

As stated in the above section, five students (15.15\%) were integratively motivated, one student (3.03\%) experienced a change in motivation, and the other 27 students $(81.82 \%)$ were instrumentally motivated.

Integrative motivation is like internal motivation, related to learners' personal interest in and attitudes towards the target language and community. Integrative motivation is about one's personal interest, desire, and persistence in learning (Tulgar, 2018, citing from Horwitz, 1987). Tulgar (2018, citing from Horwitz, 1987), further claimed that instrumental motivation is more influenced by outward factors like getting high marks on an exam or having a good job. This kind of motivation refers to the pragmatic gains that can result from the learning process (Tulgar, 2018, citing from Locastro, 2001). This is supported by Bakhtiyarovna (2021) who mentioned that in reality, if a learner is motivated internally, it will be easy to ponder everything with an inner desire. Learning obstacles and other impacts which may interfere with the learner will be tackled. However, sometimes motivation types may alter an individual.

The results of this study are supported by Wallace and Leong's (2020) study. There were 23 participants. They were sixth graders studying at a Macau primary school. The research findings revealed that the majority of the subjects had the high motivation and studied English for both instrumental and integrative reasons.

Integrative motivation centers on a desire to integrate within the target language culture. Only three students owned pure integrative motivation. Their learning motive was pure because they loved English. Five students had a combination of integrative and instrumental motivation. The majority (24) of the students had instrumental motivation. The instrumental motivations were to get a good and reputable job, be a successful person, make the parents proud, be a useful person for the nation, be a teacher, work and travel abroad, and improve the standard of living. Soureshjani and Naseri (2011) also strengthened this idea. They argued that instrumental motivation refers to the conditions in which the purpose of learning a language is to get an advantage like getting a job, promotion, or higher position and payment.

Another interesting finding in this study is that there was one student (Student 15) who had a change in motivations from instrumental to integrative motivation. In the beginning, she learned English because she wanted to be a successful person. Then as time went by, she started to enjoy the learning process and loved doing all the assignments given to her. Table 4 illustrates these types of motivations. 
TABLE 4

STUDENTS' MOTIVATIONS AND REASONS

\begin{tabular}{|c|c|c|c|}
\hline Initials & Gender & Types of Motivation & Reasons \\
\hline 1 & $\mathrm{~F}$ & Instrumental & Getting a good and reputable job \\
\hline 2 & $\mathrm{~F}$ & Instrumental & Becoming a successful person \\
\hline 3 & $\mathrm{M}$ & Integrative \& instrumental & Learning English deeper and getting a good job related to the English language \\
\hline 4 & $\mathrm{~F}$ & Instrumental & $\begin{array}{l}\text { Making the parents proud, becoming a useful person for the nation, being a } \\
\text { teacher, and building a school in a remote area }\end{array}$ \\
\hline 5 & $\mathrm{~F}$ & Instrumental & Becoming a successful person \\
\hline 6 & $\mathrm{~F}$ & Instrumental & Getting a good job soon \\
\hline 7 & $\mathrm{~F}$ & Integrative \& instrumental & $\begin{array}{l}\text { Having a love of English, making the parents proud, having a plus point, having } \\
\text { a good career, having awareness of the importance of English }\end{array}$ \\
\hline 8 & $\mathrm{~F}$ & Instrumental & Becoming a successful person $\&$ get a good job soon \\
\hline 9 & $\mathrm{M}$ & Integrative & Having a love of English \\
\hline 10 & $\mathrm{~F}$ & Integrative \& instrumental & Having a love of English \& pursuing dreams \\
\hline 11 & M & Instrumental & Having a love of English \\
\hline 12 & $\mathrm{M}$ & Instrumental & Becoming a successful person \\
\hline 13 & $\mathrm{M}$ & Integrative & Having a love of English \\
\hline 14 & $\mathrm{~F}$ & Integrative & Having a love of English \\
\hline 15 & $\mathrm{~F}$ & $\begin{array}{l}\text { Instrumental }>> \\
\text { Integrative }\end{array}$ & $\begin{array}{l}\text { Becoming a successful person \& enjoying the materials as well as assignments } \\
\text { given by the lecturers }\end{array}$ \\
\hline 16 & $\mathrm{~F}$ & Instrumental & Becoming a successful person \& pursuing her dream to be an English teacher \\
\hline 17 & M & Instrumental & Having a desire to build an English course in his hometown \\
\hline 18 & $\mathrm{~F}$ & Integrative \& instrumental & Having a love of English \& becoming a successful person \\
\hline 19 & $\mathrm{~F}$ & Integrative \& instrumental & Having the interest to learn English \& a desire to go abroad \\
\hline 20 & $\mathrm{~F}$ & Instrumental & Improving her parents' living standards \& improving her hometown \\
\hline 21 & $\mathrm{~F}$ & Instrumental & $\begin{array}{l}\text { Being a qualified English teacher, making her parents proud of her, \& having } \\
\text { self-satisfaction }\end{array}$ \\
\hline 22 & $\mathrm{~F}$ & Instrumental & Being an English teacher \\
\hline 23 & $\mathrm{~F}$ & Instrumental & Getting a good job soon \\
\hline 24 & $\mathrm{~F}$ & Instrumental & Becoming a successful person \\
\hline 25 & $\mathrm{~F}$ & Instrumental & Becoming a successful person \\
\hline 26 & M & Instrumental & Becoming a successful person \\
\hline 27 & $\mathrm{M}$ & Instrumental & Having a desire to work abroad \\
\hline 28 & $\mathrm{~F}$ & Instrumental & Becoming a successful person $\&$ building her own English course \\
\hline 29 & $\mathrm{~F}$ & Instrumental & Being an English teacher \\
\hline 30 & $\mathrm{~F}$ & Instrumental & Becoming a successful person \\
\hline 31 & $\mathrm{~F}$ & Instrumental & Being an English teacher \\
\hline 32 & $\mathrm{M}$ & Instrumental & Realizing her parents' dreams \\
\hline 33 & $\mathrm{~F}$ & Instrumental & Becoming a successful person \\
\hline
\end{tabular}

\section{E. Motivating Factors}

Besides the findings previously mentioned above, some other points need to be discussed regarding motivating and demotivating factors. From the research data, it was found that fourteen (16) students out of 33 or around 48.48\% admitted that their ideals or dreams motivated them the most. It shows that almost half of the students were driven or motivated by their dreams or ideals. The second rank after ideals or dreams is parental or family support. Eleven (11) students mentioned this. This is clarified in Table 4. Other factors included friends, teachers, and inner drive. 
TABLE 5

MOTIVATING FACTORS

\begin{tabular}{|c|c|}
\hline Students' Initials & Motivating Factors \\
\hline 1 & Ideal/ dream \\
\hline 2 & Teachers \\
\hline 3 & Ideal/ dream \\
\hline 4 & Dream, family, friends \\
\hline 5 & Family, friends \\
\hline 6 & Dream, parents, friends \\
\hline 7 & Parents \\
\hline 8 & Support from parents \\
\hline 9 & Support from parents and friends, self-motivation \\
\hline 10 & Support from parents \\
\hline 11 & Support from parents and friends, self-motivation \\
\hline 12 & Dream, family, friends, teachers \\
\hline 13 & Support from parents and friends, self-motivation \\
\hline 14 & Love of English \\
\hline 15 & Parents and teachers \\
\hline 16 & Ideal, parents and teachers \\
\hline 17 & Ideal, campus atmosphere, teachers, and friends \\
\hline 18 & Parents \\
\hline 19 & Dream \\
\hline 20 & Parents \\
\hline 21 & Ideal/ dream \\
\hline 22 & Ideal/ dream \\
\hline 23 & Ideal/ dream \\
\hline 24 & Teachers \\
\hline 25 & Ideal/ dream \\
\hline 26 & Ideal/ dream \\
\hline 27 & Ideal/ dream \\
\hline 28 & Ideal/ dream \\
\hline 29 & Ideal/ dream \\
\hline 30 & Parents \& self-motivation \\
\hline 31 & Ideal/ dream \\
\hline 32 & Parents and friends \\
\hline 33 & Ideal/ dream \\
\hline
\end{tabular}

It can be concluded that ideals or dreams can be a very strong and big drive that motivates someone in their language learning process. It is like a purpose or target to be reached at the end of the language learning journey. Learning a language without a goal or target is like driving a car without any destination.

\section{F. Demotivating Factors}

The student participants in this study experienced different things that demotivated them. Two students mentioned that they were too lazy to do their assignments. Besides laziness, many other things affected the students' learning like procrastination, boredom due to online learning, and too many assignments to do. Only two students admitted that they did not experience any demotivating factors.

The top three factors that demotivated the student participants were a habit of procrastination, too many assignments to do, and laziness. Two factors came from within the students themselves, a habit of delaying doing assignments and laziness. Those three things were the three top-ranked demotivating factors. It can be said that those factors were internal ones. It means they came from the learners.

Other factors that came from within the student participants were boredom due to the pandemic situation, a lack of self-confidence, a lack of motivation, and poor time management. Health, fatigue, and financial conditions also referred to the students' personal situations but did not deal with psychological problems. The rest of the factors were things that came from outside the participants. They were a bad Internet connection, materials, teachers, friends, assignments, bad scores, and family members' or parents' demands to get good grades. These are presented in Table 6. 
TABLE 6

FACTORS THAT DEMOTIVATED STUDENTS

\begin{tabular}{|c|c|}
\hline Students' Initials & Demotivating Factors \\
\hline 1 & Financial condition \\
\hline 2 & Bad Internet connection \\
\hline 3 & Difficult materials \\
\hline 4 & Health problems and boredom due to the pandemic situation \\
\hline 5 & Boredom and disputes with parents \\
\hline 6 & Procrastination and a lack of motivation \\
\hline 7 & Laziness \\
\hline 8 & Fatigue and a lack of facilities at home \\
\hline 9 & Laziness \\
\hline 10 & Teachers who could not understand their students' conditions \\
\hline 11 & Procrastination and too many assignments \\
\hline 12 & Nothing \\
\hline 13 & Procrastination \\
\hline 14 & Bad scores \\
\hline 15 & Too many assignments and personal problems \\
\hline 16 & Too many assignments \\
\hline 17 & Selfish friends \\
\hline 18 & Discouraging opinions from friends \\
\hline 19 & Difficult materials \\
\hline 20 & Disharmonious relationships with friends and being forced to get good grades from the family \\
\hline 21 & Things that did not happen as expected \\
\hline 22 & Too many assignments \\
\hline 23 & Lack of self-confidence \\
\hline 24 & Online learning when finishing the thesis \\
\hline 25 & Online learning when finishing the thesis, unclear teacher feedback \\
\hline 26 & Procrastination \\
\hline 27 & Too many assignments \\
\hline 28 & Teachers with unclear explanations, and teachers with favoritism \\
\hline 29 & Nothing \\
\hline 30 & Time management \\
\hline 31 & Laziness, unsupportive friends, teachers who were not nice \\
\hline 32 & Being scolded by parents due to bad scores \\
\hline 33 & Procrastination \\
\hline
\end{tabular}

Table 7 shows the demotivating factors, which are arranged alphabetically, along with the students who experienced those factors. 
TABLE 7

SUMMARY OF THE DEMOTIVATING FACTORS

\begin{tabular}{ll}
\hline Demotivating Factors & Experienced by \\
\hline Bad Internet connection & Student 2 \\
\hline Bad scores & Student 14, Student 32 \\
\hline Being forced to get good grades & Student 20 \\
\hline Boredom due to the pandemic situation & Student 4, Student 5 \\
\hline Difficult materials & Student 3, Student 19 \\
\hline Discouraging friend's opinion & Student 18 \\
\hline Disharmonious relationship with friends & Student 20 \\
\hline Disputes with parents & Student 5 \\
\hline Financial condition & Student 1 \\
\hline Health problems & Student 4 \\
\hline Lack of facilities at home & Student 18 \\
\hline Lack of motivation & Student 6 \\
\hline Lack of self-confidence & Student 23 \\
\hline Laziness & Student 7, Student 9, Student 31 \\
\hline No problems & Student 12, Student 29 \\
\hline Online learning when finishing the thesis & Student 24, Student 25 \\
\hline Personal problems & Student 15 \\
\hline Procrastination & Student 6, Student 11, Student 26, Student 33 \\
\hline Reality vs. expectations that do not meet & Student 21 \\
\hline Selfish friends & Student 17 \\
\hline Teachers who are not understanding & Student 10 \\
\hline Teachers who are not nice & Student 31 \\
\hline Teachers with unclear explanations \& high favoritism & Student 28 \\
\hline Time management & Student 30 \\
\hline Tiredness/ fatigue & Student 8 \\
\hline Too many assignments & Student 11, Student 16, Student 17, Student 27 \\
\hline Unclear teacher feedback & Student 25 \\
\hline Unsupportive friends & Student 31 \\
\hline & \\
\hline
\end{tabular}

\section{CONCLUSION}

Motivation is one of the determining factors for the success of second or foreign language learning. Without motivation, language learners will have little or no enthusiasm to learn. It is like the wheels of a car that are needed to make it keep going and moving.

From the data in this study, it was found that only four students had extrinsic motivation, while the other 29 students had intrinsic motivation. Five students $(15.15 \%)$ were integratively motivated, one student $(3.03 \%)$ experienced a change in motivation, and the remaining 27 students $(81.82 \%)$ were instrumentally motivated. It was also found that fourteen (16) students out of 33 or around $45.45 \%$ of the student respondents admitted that it was their ideals or dreams that motivated them the most. It shows that almost half of the students were driven or motivated by their dreams or ideals.

This study, however, still has some limitations. For future researchers, the number of participants can be added. Also, the participants can come from various courses as well as levels of study like secondary or tertiary education. Thus, the findings can enrich and complement the previously conducted research.

Pedagogically, this research hopefully can let teachers contemplate that they also need to accept the fact that it is their responsibility to ensure that their students are motivated and stay motivated. Teachers should not grieve the fact that students do not bring any motivation in learning an L2 in the classroom. It may be true that teachers can do little to influence students' extrinsic motivation, but there is a lot they can do to enhance their intrinsic motivation (Ellis, 2005).

\section{REFERENCES}

[1] Amjadiparvar, A. \& Zarrin, G. (2019). The Relationship between EFL learners' level of language awareness and their motivation and achievement. The Journal of Language Teaching and Learning, 2019(2), 37-48. Retrieved June 17, 2021, from http://web.a.ebscohost.com/ehost/pdfviewer/pdfviewer?vid=5\&sid=e27df39e-15b0-466c-94e3-2c9211ee3a83\%40sdc-vsessmgr01

[2] Bakhtiyarovna, R.S. (2021). The role of motivation in learning a foreign language. Elementary Education Online, 20(4), 9761980. Retrieved June 17, 2021, from http://web.a.ebscohost.com/ehost/pdfviewer/pdfviewer?vid=5\&sid=f66c1921-7dd0-4f40a537-01f63c1d1fd5\%40sdc-v-sessmgr02

[3] Bower, K. (2019). Explaining motivation in language learning: a framework for evaluation and research. The Language Learning Journal, 47(5), 558-574. https://doi.org/10.1080/09571736.2017.1321035 Retrieved June 17, 2021, from http://web.a.ebscohost.com/ehost/pdfviewer/pdfviewer?vid=8\&sid=f66c1921-7dd0-4f40-a537-01f63c1d1fd5\%40sdc-vsessmgr02

[4] Courtney, L. (2017). Transition in modern foreign languages: a longitudinal study of motivation for language learning and second language proficiency. Oxford Review of Education, 43(4), 462-481. https://doi.org/10.1080/03054985.2017.1329721 
Retrieved June 17, 2021, from http://web.a.ebscohost.com/ehost/pdfviewer/pdfviewer?vid=7\&sid=008ffc39-56ae-4816-95f89febf505c32f\%40sdc-v-sessmgr03

[5] Dornyei, Z. (1994). Motivation and motivating in the foreign language classroom The Modern Language Journal, 78(3), 273284. $\quad$ Retrieved July $19, \quad 2021$, from http://seas3.elte.hu/coursematerial/RyanChristopher/Dornyei(1994)_Foreign_Language_Classroom.pdf

[6] Ellis, R. (2005). Principles of instructed language learning. Asian EFL Journal, September 2005. Retrieved July 19, 2021, from https://asian-efl-journal.com/sept_05_re.pdf

[7] Lai, H.Y.T. (2013). The motivation of learners of English as a foreign language revisited. International Education Studies 6(10). Retrieved July 18, 2021, from https://files.eric.ed.gov/fulltext/EJ1068772.pdf

[8] Liu, C. (2020). Chinese EFL learners' motivation mediated by the perceived teacher factors - Different voices from different levels of education. Journal of Language Teaching and Research, 11(6), 920-930. Retrieved June 17, 2021, from http://web.a.ebscohost.com/ehost/pdfviewer/pdfviewer?vid=15\&sid=008ffc39-56ae-4816-95f8-9febf505c32f\%40sdc-vsessmgr03

[9] Listyani, \& Tananuraksakul, N. (2019). Motivation, self-confidence, and anxiety in English language learning: Indonesian and Thai students' perspectives. Accents Asia, 11(2), 54-77.

[10] Mahadi, T.S.T. \& Jafari, S.M. (2012). Motivation, its types, and its impacts in language learning. International Journal of Business and Social Science, 3(24). Retrieved July 19, 2021, from http://ijbssnet.com/journals/Vol_3_No_24_Special_Issue_December_2012/24.pdf

[11] Nikoopour, J., Salimian, S., Salimian, S., \& Farsani, M.A. (2012). Motivation and the choice of language learning strategies. Journal of Language Teaching and Research, 3(6), 1277-1283. DOI: 10.4304/j1tr.3.6.1277-1283. Retrieved June 19, 2021, from http://web.a.ebscohost.com/ehost/pdfviewer/pdfviewer?vid=12\&sid=008ffc39-56ae-4816-95f8-9febf505c32f\%40sdc-vsessmgr03

[12] Ning, H. \& Hornbyb, G. (2014). The impact of cooperative learning on tertiary EFL learners' motivation. Educational Review, 66, (1), 108-124. http://dx.doi.org/10.1080/00131911.2013.853169 Retrieved June 17, 2021, from http://web.a.ebscohost.com/ehost/pdfviewer/pdfviewer?vid=9\&sid=84ac593d-6146-4d9f-9bcd4d4aa4062f93\%40sessionmgr4006

[13] Olusiji, L. (2016). Parents, teachers, and peers effects on college students' motivational intensity to learn English. Language in

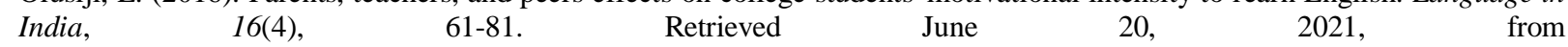
http://web.b.ebscohost.com/ehost/pdfviewer/pdfviewer?vid=8\&sid=6be2b60e-aed1-42ee-a5d9f0366991a109\%40sessionmgr101

[14] Ryan, R.M. \& Deci, E.L. (2000). Self-Determination Theory and the facilitation of intrinsic motivation, social development, and well-being. Retrieved July 8, 2021, from https://selfdeterminationtheory.org/SDT/documents/2000_RyanDeci_SDT.pdf

[15] Sabet, M.K., Tahriri, A.T., Haghi, E.B. (2014). The impact of Task-based Approach on Iranian EFL learners' motivation in writing research. Journal of Language Teaching and Research, 5(4), 953-962. Retrieved June 18, 2021, from http://web.a.ebscohost.com/ehost/pdfviewer/pdfviewer?vid=6\&sid=ae2de997-4c7c-414a-9a70-6e863246c7ea\%40sdc-vsessmgr03

[16] Soureshjani, K.H. \& Naseri, N. (2011). The Interrelationship of Instrumental, Integrative, Intrinsic, and Extrinsic Motivations and the Lexical-oriented Knowledge among Persian EFL Language Learners. Theory and Practice in Language Studies, 1(6), 662-670. $\quad$ Retrieved July $18, \quad 2021, \quad$ from https://www.researchgate.net/publication/276247615_The_Interrelationship_of_Instrumental_Integrative_Intrinsic_and_Extrin sic_Motivations_and_the_Lexical-oriented_Knowledge_among_Persian_EFL_Language_Learners

[17] Tulgar, A.T. (2018). A case study on the effects of glocal second language setting on the language learning motivation of foreign learners of Turkish. International Journal of Multicultural Education, 20(3), 80-102. Retrieved June 18, 2021, from http://web.a.ebscohost.com/ehost/pdfviewer/pdfviewer?vid=9\&sid=008ffc39-56ae-4816-95f8-9febf505c32f\% 40 sdc-vsessmgr03

[18] UKEssays. (2018). The three-circle model of world Englishes. Retrieved June 16, 2021, from https://www.ukessays.com/essays/english-literature/three-circle-model-of-world-englishes-english-literature-essay.php?vref=1

[19] Valpa. A. (2020). Kachru model "The three circle of English". Retrieved June 15, 2021, from https://agvalpa.medium.com/kachru-model-the-three-circles-of-english-b53b86e63d46

[20] Wallace, M.P. \& Leong, E.I.L. (2020). Exploring language learning motivation among primary EFL learners. Journal of Language Teaching and Research, 11(2), 221-230. Retrieved June 17, 2021, from http://web.a.ebscohost.com/ehost/pdfviewer/pdfviewer?vid=21\&sid=008ffc39-56ae-4816-95f8-9febf505c32f\%40sdc-vsessmgr03

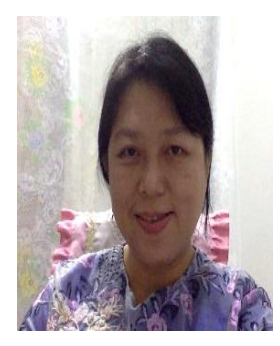

Listyani graduated from the English Department (ED), Faculty of Education and Teacher Training (FKIP), UKSW, Salatiga, Indonesia in 1995. She got her Magister Humaniora degree (Master of Humanity Studies) from the English Language Studies (ELS) Program, Sanata Dharma University Yogyakarta, Indonesia, in 2006. In August 2017, she got her Doctorate degree from State University of Semarang (UNNES) Indonesia, majoring in English Language Education. She is now a lecturer, researcher, and professor at the English Language Education Program (ELEP), Faculty of Language and Arts (FLA), Universitas Kristen Satya Wacana (UKSW) Salatiga, Indonesia. She has been teaching there since March 1999. In November 2020, she got her professorship from the Indonesian Government, majoring in English Language Education. Her research interests are SLA, Academic Writing, Teacher Training, Teacher Professional Development, and TEYL. 